\title{
Occurrence of Serum Antibodies Against Wheat Alpha-Amylase Inhibitor 0.19 in Celiac Disease
}

\author{
D. SÁNCHEZ ${ }^{1}$, S. ŠTĚPÁNOVÁ HONZOVÁ ${ }^{2}$, M. HOSPODKOVÁ ${ }^{2}$, I. HOFFMANOVÁ ${ }^{3}$, \\ V. HÁBOVÁ ${ }^{1}$, P. HALADA ${ }^{1}$, H. TLASKALOVÁ-HOGENOVÁ ${ }^{1}$, L. TUČKOVÁ ${ }^{1}$ \\ ${ }^{1}$ Laboratory of Cellular and Molecular Immunology, Institute of Microbiology of the Czech \\ Academy of Sciences, Prague, Czech Republic, ${ }^{2}$ synlab czech Ltd., Prague, Czech Republic, \\ ${ }^{3}$ Second Department of Internal Medicine, Third Faculty of Medicine, Charles University in Prague \\ and University Hospital Královské Vinohrady, Prague, Czech Republic
}

Received January 31, 2018

Accepted February 12, 2018

On-line May 10, 2018

\section{Summary}

The alcohol-soluble fraction of wheat gluten (gliadins) induces in genetically susceptible individuals immunologically mediated celiac disease (CLD). However, gliadins and related cereal proteins are not unique foodstuff targets of CLD patients' immune system. Non-gluten wheat alpha-amylase inhibitor 0.19 (AAI 0.19) has been found to be capable of activating human monocyte-derived dendritic cells and inducing pro-inflammatory status in intestinal mucosa of patients with celiac disease (CLD). The possible contribution of this reactivity in incomplete remission of CLD patients on a gluten-free diet (GFD) is matter of contention. In an attempt to characterize the antigenicity of AAI 0.19 in patients with active CLD, patients on a GFD and healthy controls we developed ELISA employing wheat recombinant AAI 0.19 . Using this test we revealed a significant $(P<0.001)$ elevation of IgA anti-AAI 0.19 antibodies $(A b)$ in patients with active CLD (12 out of 30 patients were seropositive) but also in CLD patients on a GFD (15/46), in contrast to healthy controls (2/59). Anti-AAI $0.19 \mathrm{IgG}$ Ab levels were increased $(P<0.001)$ only in patients with active CLD $(14 / 30)$ in contrast to the controls. Interestingly, the levels of anti-AAI $0.19 \mathrm{IgG} A b$ were decreased in CLD patients on a GFD $(P<0.001,1 / 46)$ compared to the controls $(1 / 59)$. Notably, 20 out of 30 patients with active CLD were positive either for IgA or for IgG antiAAI $0.19 \mathrm{Ab}$. Thus, the majority of CLD patients developed a robust IgA and IgG $A b$ response against AAI 0.19. These findings may contribute to the broadening of the knowledge about CLD pathogenesis.

\section{Key words}

Alpha-amylase inhibitor $0.19 \bullet$ Celiac disease • Gluten-free diet • IgA • IgG • ELISA

\section{Corresponding author}

D. Sánchez, Laboratory of Cellular and Molecular Immunology, Institute of Microbiology of the Czech Academy of Sciences, Vídeňská 1083, 14220 Prague, Czech Republic. Fax: +420 241 062 458. E-mail: sanchez@biomed.cas.cz

\section{Introduction}

Cereals belong to the most important sources of nutrients in the world, with dominance of consumption in Europe and America. It should be noted, however, that wheat induces morbidity in over $2 \%$ of the word population. Generally, the main pathological conditions related with molecules of wheat grain are celiac disease (CLD), wheat allergy and non-celiac wheat sensitivity (Elli et al. 2015). The CLD affects nearly 1:100-200 of the wheat consumers in Europe, North America and North Africa; nevertheless, a substantial part of patients are undiagnosed due to clinically silent (asymptomatic) form(s) of the disease (Brar et al. 2006, Parada et al. 2011, Gujral et al. 2012, Kasarda 2013, Lebwohl et al. 2018). The CLD is induced in genetically susceptible individuals by ingestion of alcohol-soluble fraction of gluten (wheat-grain storage proteins) - gliadins and phylogenetically related cereals' proteins: hordeins in 
barley, secalins in rye and certain avenins in oats. The alimentary intake of these proteins induces in CLD patients villous atrophy and crypt hyperplasia in duodenum and jejunum mucosa accompanied by malabsorption and gastrointestinal symptoms caused by the loss of digestive and barrier functions. The failure of oral tolerance to cereal prolamins and elicitation of T-cell mediated autoimmunity are considered as pathological mechanisms of CLD. Active CLD is serologically characterized by production of antibodies (Ab) against induction agents of CLD - gliadins and various $\mathrm{Ab}$ against food antigens and autoantibodies, and a characteristic cytokine pattern. The testing of $\mathrm{Ab}$ against tissue transglutaminase (tTG) and deamidated gliadin or antibodies against endomysium is used in CLD diagnostics and verification of compliance to gluten-free diet (GFD), a sole rational life-long therapy of CLD. The adherence to GFD leads to healing of mucosal damage and disappearance of $\mathrm{Ab}$ against $\mathrm{tTG}$, endomysium and gliadins (Catassi and Fasano 2010, Husby et al. 2012, Nevoral et al. 2014, Björck et al. 2015, Balakireva and Zamyatnin 2016, Wolf et al. 2017). Although a longlasting and incomplete histological recovery, persistence of symptoms and discrepancy in serum levels of $\mathrm{Ab}$ against tTG and deamidated gliadin in CLD patients on a GFD may occur, the histological analysis of smallintestinal mucosa is not usually performed in a follow-up of these patients (Wahab et al. 2002, Tursi et al. 2003, Osman et al. 2014, Pekki et al. 2017, Burger et al. 2017). However, gliadins and related cereal proteins are not unique foodstuff targets of CLD patients' immune system. The possible contribution of this reactivity in incomplete remission of CLD patients on a GFD is matter of contention. Huebener et al. (2015) described in CLD patients serum $\mathrm{IgA}$ and $\mathrm{IgG} \mathrm{Ab}$ recognizing a number of non-gluten proteins extracted from U.S. hard red spring wheat Triticum aestivum Butte 86 flour: serpins, purinins, globulins, farinins and several alpha-amylase/protease inhibitors. Interestingly, alpha-amylase inhibitor/trypsin inhibitor CM3 and alpha-amylase inhibitor (AAI) 0.19, a pest resistance molecule in wheat, were recently identified as potent activators of innate immune response in human monocyte-derived dendritic cells of both patients with active CLD and CLD patients on a GFD eliciting secretion of IL-8. Consistently, enterobiopsy specimens from CLD patients in remission cultivated in a medium with alpha-amylase/trypsin inhibitors caused an increase of IL- 8 mRNA expression. Moreover, these inhibitors stimulated also monocyte-derived dendritic cells of healthy controls to production of IL-12. The adjuvant effect of these molecules was mediated by their interaction with TLR4-MD2-CD14 complex (Junker et al. 2012). The AAI 0.19 and AAI 0.28 were originally described as allergens in baker's asthma (Walsh and Howden 1989, Pfeil et al. 1990, Fränken et al. 1994, Amano et al. 1998). Subsequently, these AAIs were also identified as one of the major wheat allergens in wheat allergy (James et al. 1997, Zapatero et al. 2003, Šotkovský et al. 2008, Šotkovský et al. 2011, KusabaNakayama et al. 2001).

The hydrosoluble allergens AAI 0.19 with adjuvant properties are structurally and physicochemically different from water-insoluble gliadins. We hypothesized that AAI 0.19 could play a role in pathogenesis of CLD. Thus, we focused on analysis of the role of AAI 0.19 in CLD via the study of its antigenicity. In an attempt to characterize the antibody response to AAI 0.19 in patients with active CLD, patients on a GFD and healthy controls, we used an immunoblot technique employing the mixture of isolated wheat AAI 0.19 and AAI 0.28, and developed a reproducible, robust ELISA test for quantification of serum IgA and IgG antibodies against AAI 0.19 protein.

\section{Material and Methods}

\section{Patients and healthy controls}

The sera of 30 patients with active CLD (24 adults, 6 pediatric patients) were encompassed in our study. The group of adult patients comprised 16 women and 8 men with a mean age of 41.9 years, ranging from 21-76 years. Pediatric patients included 4 females and 2 males with mean age 6.8 years, range $3-13$ years. The CLD was diagnosed on the basis of modified ESPGAN criteria (Husby et al. 2012). The active CLD, i.e. CLD patients at the time of diagnosis, were positive for the serological CLD markers IgA anti-tissue transglutaminase (anti-tTG), IgA Ab and IgG anti-endomysial Ab (EMA) and $\mathrm{Ab}$ against deaminated gliadin. The pathological lesions in small bowel mucosa of these patients with active CLD were estimated at Marsh IIIA-IIIC. The Marsh IIIC grading was present in three, Marsh IIIB in 10 and Marsh IIIA in 11 out of 24 adult active CLD patients. Five out of six children patients met the new ESPGHAN guidelines (Husby et al. 2012) for omitting the small gut biopsy; these patients were symptomatic and highly seropositive for anti-tTG $\mathrm{Ab}$ (with titers of more than 10 times the upper limit of normal), positive for EMA 
and simultaneously possessing the HLA-DQ2.5 and/or DQ8 haplotypes. One child with CLD, positive for the CLD serological and genetic markers and manifesting gastrointestinal symptoms, was assessed as Marsh IIIA (male, 13 years).

The cohort of 46 CLD-GFD patients comprised 42 adults patients (31 women, 11 men) with mean age 39, ranging $19-77$ years and 4 children ( 1 female, 3 male) with mean age 6.5 ranging 5-7 years with compliance to GFD for at least 12 months. All of these patients were seronegative for EMA and anti-tTG Ab, and free of CLD symptoms.

The control group consisted with 59 healthy individuals ( 28 women, 31 men), mean age 35.4 , range 21-76 years. Individuals in the cohort were free of symptoms of gastrointestinal, autoimmune, inflammatory, malignant, allergic and infectious diseases and were seronegative for CLD markers.

The study was approved by the Local Ethics Committees from the Faculty Hospital Královské Vinohrady in Prague (Czech Republic) and the synlab czech Ltd. (Czech Republic). Written informed consent was obtained from each participant in this study.

\section{SDS-PAGE, Western blot analysis}

The protein separation was performed using sodium dodecyl sulfate electrophoresis (SDS-PAGE) under reducing conditions as described by Laemmli and Favre (1973). A mixture of isolated wheat AAI 0.19 and AAI 0.28, dominant components of the "Alpha-amylase inhibitor from Triticum aestivum (wheat seed), Type III, A3535" (Sigma-Aldrich, USA), was characterized by MALDI-TOF mass spectrometry on a Ultraflex III instrument equipped with LIFT technology (Bruker Daltonics, Bremen, Germany). The mixture of AAI 0.19 and AAI 0.28, and wheat recombinant AAI 0.19 (Apronex, Czech Republic) were initially dissolved in phosphate buffered saline (PBS) $(0.154 \mathrm{M} \mathrm{NaCl}$, $1.4 \mathrm{mM} \mathrm{NaH}_{2} \mathrm{PO}_{4} .2 \mathrm{H}_{2} \mathrm{O}, 3.35 \mathrm{mM} \mathrm{Na} \mathrm{NPO}_{4} .12 \mathrm{H}_{2} \mathrm{O}$ ) at a concentration of $5 \mu \mathrm{g} / \mu \mathrm{l}$ and $1 \mu \mathrm{g} / \mu \mathrm{l}$, respectively (stock solution) and finally diluted 3:1 in sample buffer containing $0.25 \mathrm{M}$ Tris (Serva, Germany) (pH 6.8), $8 \%$ SDS (Serva), $40 \%$ glycerol (Lachema, Czech Republic), $0.05 \mathrm{M}$ Dithiothreitol (Sigma-Aldrich, USA) and $0.01 \%$ bromophenol blue (Lachema). Samples of the mixture of AAIs in sample buffer were boiled prior to separation due to better resolution and subsequently loaded into $15 \%$ polyacrylamide gel in device Mini-Protean ${ }^{\circledR} 3$ Cell device (Bio-Rad, USA) connected to a EC 6000-90 power supply (EC Apparatus Corporation, USA) and separated under electric conditions $(35 \mathrm{~mA}, 150 \mathrm{~V}$ and $200 \mathrm{~W})$ for 45-50 min. The sample of recombinant wheat AAI 0.19 was not boiled prior to separation by SDS-PAGE under the same conditions as the mixture of isolated wheat inhibitors. Separated proteins were transferred to a nitrocellulose membrane (Amersham ${ }^{\mathrm{TM}}$ Hybond $^{\mathrm{TM}}$-ECL, GE Healthcare Live Sciences, United Kingdom) in buffer containing glycine (192 mM, Serva), Tris $(24.7 \mathrm{mM}$, Serva) and $20 \%$ methanol (Lach-Ner, Czech Republic) using the Trans-Blot (Bio-Rad) and PowerPac ${ }^{\mathrm{TM}}$ Universal power supply (Bio-Rad) under $250 \mathrm{~mA}, 500 \mathrm{~V}$ and $200 \mathrm{~W}$ for $50 \mathrm{~min}$. The nitrocellulose membrane was cut into strips. The strips were blocked with $2 \%$ non-fat powdered milk (ARTIFEX Instant, Czech Republic) in PBS containing $0.2 \%$ Tween 20 (Serva) (PBS-T (0.2 \%)) for $1 \mathrm{~h}$ at room temperature (RT) and then incubated with patients' or control sera diluted at 1:500 (in case of $\operatorname{IgA}$ ), 1:2,500 (IgG) and 1:40 (IgE) in 1\% non-fat powdered milk in PBS-T $(0.2 \%)$ overnight at $4{ }^{\circ} \mathrm{C}$. After washing with PBS-T $(0.2 \%)$, the goat secondary peroxidase conjugated $\mathrm{Ab}$ against human IgA or IgG (The Binding Site, United Kingdom) diluted at $1: 5,000$ or $\operatorname{IgE}$ (Invitrogen, USA) diluted at $1: 10,000$ in $1 \%$ non-fat powdered milk in PBS-T (0.2\%) was added. After 1-h incubation at RT and repeated washing, ECL reagent SuperSignal ${ }^{\mathbb{B}}$ West Pico (IgA, IgG) and SuperSignal ${ }^{\mathbb{}}$ West Femto (IgE) (Thermo SCIENTIFIC, USA) was added and autoradiography (MXBE Film, Carestream Health France, France) were used for chemiluminescence detection.

\section{Estimation of antibodies to alpha-amylase inhibitor 0.19}

Wheat recombinant AAI 0.19 was used at a final concentration of $50 \mu \mathrm{g} / \mathrm{ml}$ in PBS. The 96-well polystyrene microtiter plates (Gama, České Budějovice, Czech Republic) were coated overnight at $4{ }^{\circ} \mathrm{C}$. Blocking solution $-1 \%$ BSA (Sigma-Aldrich, USA) in PBS was also used as a negative control. Patients' and reference sera were diluted in blocking solution at 1:20 and 1:100 in case of detection of anti-AAI 0.19 IgA Ab and 1:100 and 1:500 in case of detection of anti-AAI 0.19 $\operatorname{IgG~Ab}$, and incubated overnight at $4{ }^{\circ} \mathrm{C}$ in wells of microtiter plates. Each dilution of patients' and reference sera was tested in triplicate. The testing of anti-AAI $\mathrm{Ab}$ was performed in at least two independent experiments; the results obtained for individual serum were averaged. After incubation, the plates were repeatedly washed with PBS and PBS containing $0.05 \%$ of Tween 20 (PBS-T $(0.05 \%))$ and subsequently peroxidase-labeled goat anti- 
human $\operatorname{Ig} \mathrm{A}$ or $\operatorname{IgG} \mathrm{Ab}$ (The Binding Site) diluted at 1:750 in $10 \%$ normal goat serum (Sigma-Aldrich) in PBS (IgG) or in PBS containing $10 \%$ normal goat serum and $1 \%$ BSA (IgA) were added to the wells. After 1-h incubation at $\mathrm{RT}$, the plates were repeatedly washed with PBS and PBS-T and the enzyme reaction was developed by adding a solution containing $3.87 \mathrm{mM}$ o-phenylenediamine dihydrochloride (Sigma-Aldrich) in $0.1 \mathrm{M}$ phosphate buffer $\left(0.1 \mathrm{M} \mathrm{NaH} \mathrm{PO}_{4} .2 \mathrm{H}_{2} 0,0.1 \mathrm{M}\right.$ $\left.\mathrm{Na}_{2} \mathrm{HPO}_{4} .12 \mathrm{H}_{2} \mathrm{O}, \quad \mathrm{pH} 6.0\right)$ containing $0.06 \% \mathrm{H}_{2} \mathrm{O}_{2}$ (Chemapol, Czech Republic). The reaction was stopped by $2 \mathrm{M} \mathrm{H}_{2} \mathrm{SO}_{4}$ and optical density was read at $492 \mathrm{~nm}$ on a spectrophotometer Titertek Multiscan ${ }^{\circledR} \quad \mathrm{MCC} / 340$ ELISA Reader (Eflab, Finland) and BioTek ${ }^{\circledR}$ EL800 (BioTek, USA).

The internal laboratory standard (reference serum) was prepared from pooled celiac patients' sera and was used in all ELISA tests. The serum levels of antiAAI $0.19 \mathrm{Ab}$ were expressed as arbitrary units (AU), represent the percentage of optical density (O. D.) of individual samples to O. D. of reference serum. Cut-off value, a threshold above which we take the individual positive, was calculated as the mean + double standard deviation of levels of IgA or IgG anti-AAI 0.19 in healthy donor group (healthy controls).

\section{Statistical analysis}

The Ab levels are usually not directly proportional to antigen-binding capacity of serum samples (Arranz and Ferguson 1993). In most cases, non-parametric tests are appropriate for analysis of immunohematological data (Reverberi 2008). We analyzed for Gaussian distribution of anti-AAI 0.19 Ab levels in all cohorts by D'Agostino-Pearson omnibus normality test and Shapiro-Wilk normality test. Using the tests a non-Gaussian distribution of $\operatorname{IgA}$ or IgG antiAAI 0.19 Ab levels was revealed in groups of patients with CLD and CLD-GFD patients. For this reason, we used Mann-Whitney $\mathrm{U}$ test for comparison of $\mathrm{Ab}$ levels between groups.

\section{Results}

Western blot analysis of antigenicity of AAI 0.19 and AAI 0.28 using a mixture of isolated wheat proteins

In the first stage of our study of occurrence of anti-AAI Ab in CLD we estimated, by Western blotting with a mixture of isolated wheat AAI 0.19 and AAI 0.28 separated by SDS-PAGE, serum IgA, IgG and IgE Ab reactivity in active CLD patients, CLD-GFD patients and healthy controls (Fig. 1, Table 1). Employing this technique, we detected reactivity of IgA anti-AAI 0.19 and/or anti-AAI 0.28 in eight out of 30 active CLD patients, in five out of 46 CLD-GFD and five out of 59 healthy controls. Moreover, also 13 out of 30 active CLD, 3 out of 46 CLD-GFD patients and 5 out of 59 healthy individuals were seropositive for $\mathrm{IgG}$ isotype of these $\mathrm{Ab}$. Surprisingly, the $\mathrm{IgE} \mathrm{Ab}$ recognizing AAI 0.19 and/or AAI 0.28 were also found in 12 out of $30 \mathrm{CLD}$, in 6 out of $46 \mathrm{CLD}-\mathrm{GFD}$, and 5 out of 59 healthy controls.

ELISA for quantification of $\operatorname{Ig} A$ and $\operatorname{Ig} G$ Ab against wheat recombinant

AAI 0.19

The purpose of ELISA was to precisely characterize the antigenicity and compare the serum levels of $\operatorname{IgA}$ and $\operatorname{IgG~Ab}$ (isotypes associated with active CLD) against AAI 0.19 in patients with active CLD, CLD on a GFD and healthy controls. The capability of binding of serum IgA (Fig. 2A) and IgG Ab (Fig. 2B) to recombinant wheat AAI 0.19 was verified by titration analyses. The slope of the titration curve of $\mathrm{Ab}$ of the majority of tested sera was similar, indicating their similar specificity for AAI 0.19 . For better resolution of the ELISA test, we used two dilutions of tested sera for quantification of the level of anti-AAI $0.19 \mathrm{Ab}$. We estimated the optimal dilution of sera for testing $\mathrm{Ab}$ against wheat recombinant AAI 0.19 in the ELISA at $1: 20$ and $1: 100$ for $\operatorname{IgA}$ and $1: 100$ and $1: 500$ for $\operatorname{IgG~Ab.~}$ The results from individual dilutions of sera samples (in triplicate) were averaged.

Comparison the seropositivity and serum levels of $\operatorname{IgA}$ and $\operatorname{IgG} \mathrm{Ab}$ against AAI 0.19 in patients with active CLD, CLD on a GFD and healthy controls is given in Table 2 and Figure 3. The ELISA detected statistically significantly elevated $(\mathrm{P}<0.001) \mathrm{IgA}$ anti-AAI $0.19 \mathrm{Ab}$ in patients with active CLD $(117.2 \pm 105.3 \mathrm{AU}$, mean \pm standard deviation) and even in CLD-GFD (80.1 \pm 43.6 $\mathrm{AU})$ in contrast to healthy controls (50.5 $\pm 24.3 \mathrm{AU})$. Although we detected reduced average level of $\operatorname{IgA}$ anti-AAI 0.19 Ab in a cohort of CLD-GFD in comparison with active CLD, the difference between the values of averages of the $\mathrm{Ab}$ levels was not statistically significant. The serum levels of IgA anti-AAI $0.19 \mathrm{Ab}$ in 12 out of 30 CLD patients, in 15 out of 46 CLD-GFD patients and in 2 out of 59 healthy controls exceeded cut-off value (99 AU), above which we take the individual seropositive. 


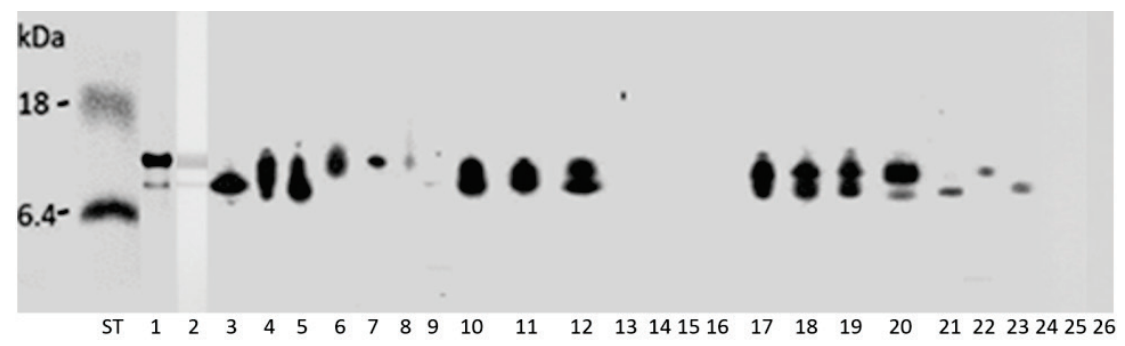

Fig. 1. Examples of reactivity of IgA, IgG and IgE serum antibodies (Ab) of celiac (CLD) patients, those on gluten-free diet (CLD-GFD) and healthy controls (C) with isolated wheat alpha-amylase inhibitor 0.19 and alpha-amylase inhibitor 0.28 . Proteins were separated by $15 \%$ polyacrylamide gel with sodium dodecyl sulfate electrophoresis (SDS-PAGE), stained with Coomassie brilliant blue R-250 and subsequently blotted into nitrocellulose membrane.

ST, molecular weight standards (kDa); lane 1: SDS PAGE of alpha-amylase inhibitors $0.19(\sim 15 \mathrm{kDa})$ and truncated $0.28(\sim 11 \mathrm{kDa})$; lane 2: Ponceau $S$ stained Western blot of separated inhibitors transferred into the membrane; lanes 3-5: IgA Ab reactivity of CLD patients; lanes 6, 7: IgA Ab reactivity of CLD-GFD; lanes 8, 9: weak reactivity of IgA Ab of C; lanes 10-12: IgG Ab reactivity of CLD patients; lanes 13, 14: IgG Ab reactivity of CLD-GFD; lanes 15, 16: reactivity of IgG Ab of C; lanes 17-19: IgE Ab reactivity of CLD patients; lanes 20, 21: reactivity of IgE Ab of CLD-GFD; lanes 22, 23: weak reaction of IgE Ab of C. Negative controls (without employing patients or control serum) represent only anti-IgA Ab peroxidase labeled Ab (lane 24), anti-IgG peroxidase labeled Ab (lane 25) and anti-IgE peroxidase labeled Ab (lane 26).

Table 1. Fraction of seropositive individuals for antibodies against wheat alpha-amylase inhibitor 0.19 and/or 0.28 detected by Western blot.

\begin{tabular}{lccc}
\hline Cohorts & IgA & IgG & IgE \\
\hline$C L D$ & $8 / 30(27 \%)$ & $13 / 30(43 \%)$ & $12 / 30(40 \%)$ \\
$C L D-G F D$ & $5 / 46(11 \%)$ & $3 / 46(\sim 7 \%)$ & $6 / 46(13 \%)$ \\
Healthy controls & $5 / 59(\sim 8 \%)$ & $5 / 59(\sim 8 \%)$ & $5 / 59(\sim 8 \%)$ \\
\hline
\end{tabular}

CLD, celiac disease; CLD-GFD, CLD on a gluten-free diet; IgA, IgG, IgE, antibody isotypes; number of seropositive individuals/total number in cohort.

A
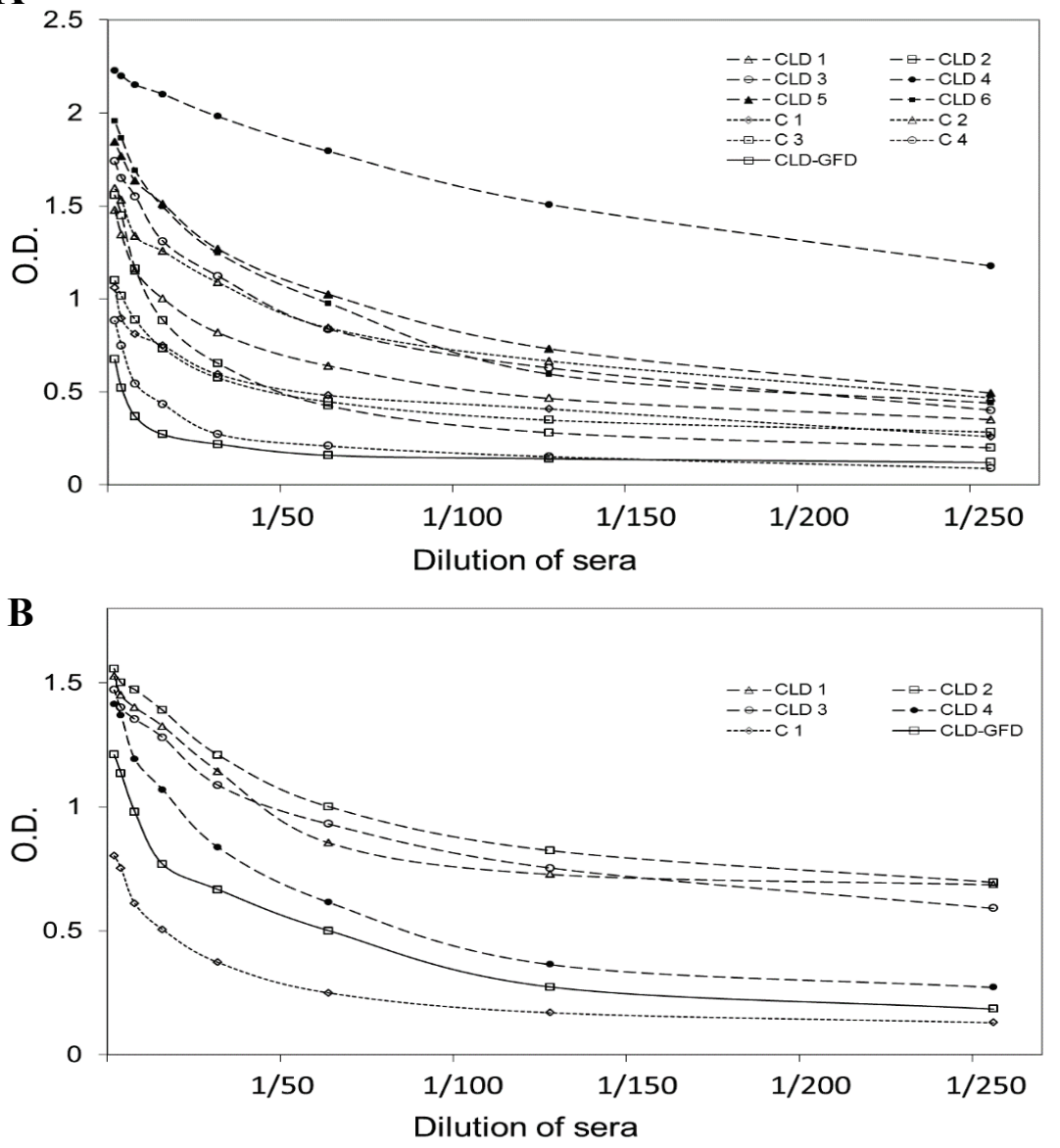

Fig. 2. Titration curves of serum IgA (A) and IgG (B) antibodies (Ab) against recombinant wheat alpha-amylase inhibitor 0.19 in active celiac patients (CLD 1-6), healthy controls (C 1-4) and celiac patients on a gluten-free diet (CLD-GFD). O.D., optical density, dilution of sera is indicated at horizontal axis. 
The IgG anti-AAI $0.19 \mathrm{Ab}$ were significantly $(\mathrm{P}<0.001$, $149 \pm 78.4 \mathrm{AU}$ ) elevated only in patients with active CLD, while they were significantly decreased in CLD-GFD patients $(\mathrm{P}<0.001,59 \pm 37.1 \mathrm{AU})$ when compared to both patients with active CLD and healthy controls (82.7 $\pm 33.7 \mathrm{AU})$. The 14 out of 30 CLD patients, 1 out of 46 CLD-GFD patients and 1 out of 59 healthy controls were seropositive for IgG anti-AAI 0.19 Ab (cut-off value $150 \mathrm{AU}$ ). Taken together, 6 out of 30 active CLD patients were seropositive for both isotypes of anti-AAI $0.19 \mathrm{Ab}$. However, 20 out of 30 CLD patients were seropositive either for IgA or for IgG anti-AAI Ab. The IgA and IgG Ab reactivity of CLD patients, those on a GFD and healthy controls (C) with recombinant wheat AAI 0.19 was confirmed using Western blot (Fig. 4).

Table 2. Seropositive individuals for antibodies against recombinant wheat alpha-amylase inhibitor 0.19 detected by ELISA.

\begin{tabular}{lcc}
\hline Cohorts & IgA & IgG \\
\hline$C L D$ & $12 / 30(40 \%)$ & $14 / 30(\sim 47 \%)$ \\
$C L D-G F D$ & $15 / 46(\sim 33 \%)$ & $1 / 46(\sim 2 \%)$ \\
Healthy controls & $2 / 59(\sim 3 \%)$ & $1 / 59(\sim 2 \%)$ \\
\hline
\end{tabular}

CLD, celiac disease; CLD-GFD, CLD on a gluten-free diet; IgA, IgG, antibody isotypes; number of seropositive individuals (Ab levels exceeding the cut-off value)/total number in the cohort.

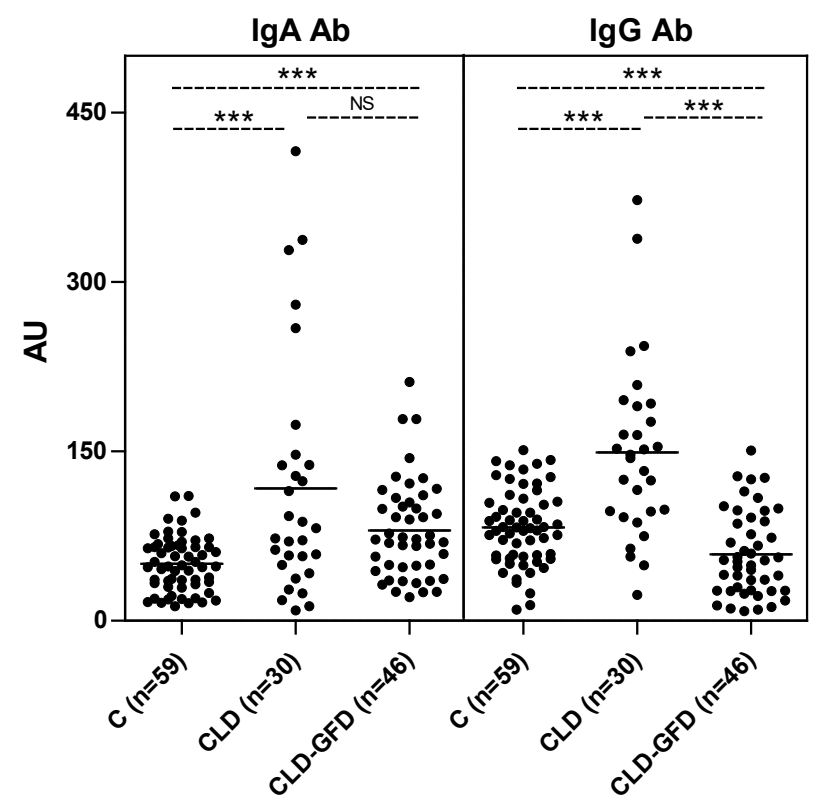

Fig. 3. Distribution of individual serum levels of $\mathrm{IgA}$ and $\mathrm{IgG}$ antibodies $(\mathrm{Ab})$ against recombinant wheat alpha-amylase inhibitor 0.19 (AAI 0.19) in patients with celiac disease (CLD), CLD on a gluten-free diet (CLD-GFD) and healthy controls (C). Horizontal lines indicate the mean serum levels of specific antibodies in cohorts. AU, arbitrary units; n, number of patients; $* * * \mathrm{P}<0.001$; NS, not significant. Cut-off value for IgA antiAAI $0.19 \mathrm{Ab}$ is $99 \mathrm{AU}$ and for IgG anti-AAI 0.19 Ab $150 \mathrm{AU}$.

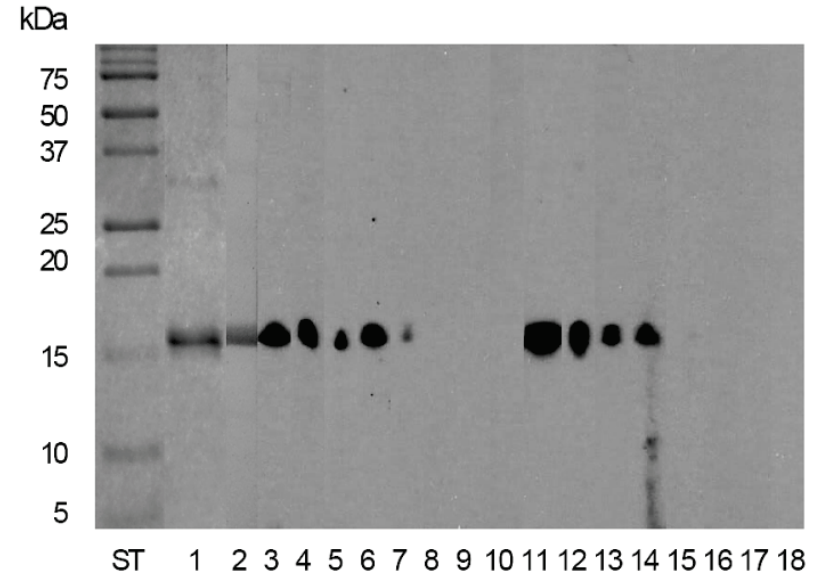

Fig. 4. Verification of $I g A$ and $I g G$ antibodies (Ab) reactivity of celiac patients (CLD), CLD patients on a gluten-free diet (CLD-GFD) and healthy controls (C) with recombinant wheat alfa-amylase inhibitor 0.19 using Western blot. ST, molecular weight standards $(\mathrm{kDa})$; Lane 1 indicates position of recombinant wheat alfaamylase inhibitor 0.19 in SDS-PAGE electrophoretogram, stained by Coomassie brilliant blue R-250. The image of inhibitor blotted into nitrocellulose membrane and visualized by Ponceau $S$ is localized in lane 2. The intensity of IgA Ab reactivity of CLD patients with wheat alpha-amylase inhibitor 0.19 is demonstrated in lanes 3-5 (CLD), lanes 6, 7 (CLD-GFD), and lanes 8, 9 (C). Lane 10 indicates negative control - immunoblot with only peroxidase-conjugated anti-human IgA Ab. Examples of IgG Ab reactivity with the inhibitor are indicated in lanes 11-13 (CLD) and lanes 14, 15 (CLD-GFD). Lanes 16 and 17 document non-reactive IgG $\mathrm{Ab}$ of healthy controls. Lane 18 represents negative control - immunoblot with only peroxidase-conjugated anti-human IgG Ab.

\section{Discussion}

In genetically susceptible individuals, nutrient components may induce an immunologically-mediated food intolerance or hypersensitivity. Wheat amylase/trypsin inhibitors belong to the ubiquitous group of small naturally occurring pest-resistance proteins (Ryan 1990, Cordain 1999). Recently, wheat AAI 0.19 was identified as a potent activator of human monocytederived dendritic cells of both patients with active CLD and CLD patients on a GFD, and in healthy controls via interaction with the TLR4-MD2-CD14 complex (Junker et al. 2012). Subsequently, the antigenicity of alphaamylase/protease inhibitors for CLD patients was detected in the study of Huebener et al. (2015). The TLR4-mediated adjuvant effect of amylase/trypsin inhibitors in gluten-containing samples (irrespectively whether baked or otherwise processed) induced infiltration and activation of myeloid cells as well as release of inflammatory mediators in intestinal mucosa of experimental mice (Zevallos et al. 2017). Moreover, wheat amylase/trypsin inhibitors were suggested as causative agents of non-celiac wheat sensitivity through 
activation of patients' immune system via the TLR4 (Schuppan and Zevallos 2015). These inhibitors have been known for years to induce a rapid increase of proinflammatory cytokines and chemokines in CLD patients in remission after a duodenal and rectal wheat challenge (Kontakou et al. 1995, Chowers et al. 1997). However, no information is available on the adaptive immune response against these amylase/trypsin inhibitors in CLD patients.

In the present study, we focused on characterizing $\mathrm{Ab}$ against wheat AAI 0.19 (and AAI 0.28) in CLD patients and those on a GFD for the first time. Using Western blot with a mixture of isolated wheat AAIs as antigens, we found relatively high frequency of CLD patients seropositive for anti-AAI 0.19 and/or anti-AAI $0.28 \mathrm{IgA}, \quad \mathrm{IgG}$, and $\operatorname{IgE} \mathrm{Ab}$. Consequently, we confirmed these results for $\operatorname{IgA}$ and IgG isotypes using quantitative ELISA. For this purpose, we developed ELISA employing recombinant wheat AAI 0.19 as an antigen. Despite the fact that AAI 0.19 represents a negligible part of wheat grain, 20 out of 30 CLD patients were seropositive either for IgA or for $\mathrm{IgG}$ isotype of anti-AAI $\mathrm{Ab}$. The frequency and distribution of individual values of $\operatorname{IgA}$ and $\operatorname{IgG} \mathrm{Ab}$ against AAI 0.19 in our study suggest a genetically controlled predisposition to immune response against AAI 0.19 , which is reinforced by natural adjuvant effect described by Schuppan and Zevallos (2015). On the other hand, we can also assume the contribution of impaired barrier function of CLD patients' intestine to the development of anti-AAIs $\mathrm{Ab}$ enabling increased penetration of the AAIs (and other food antigens) through mucosa.

High levels of IgA and IgG Ab against AAI 0.19 in patients with CLD document advanced immune response of long duration indicating a germinal center reaction in lymphoid follicles and cooperation with antigen-specific CD4+ T-cells. In general, it is assumed that the high antigen-Ab (B-cell receptor) avidity complexes promote extrafollicular B-cell response and increase plasma cell generation (Chan and Brink 2012). Consistent with this, the extrafollicular response or a short-time germinal reaction is assumed in the development of tTG specific B-cells (and the production of low avidity autoAb). It could be triggered by selfoligomerization of this CLD autoantigen (Gelderman et al. 2014, Stamnaes et al. 2015). Remarkably, the capability of oligomerization is also characteristic for alpha-amylase inhibitors; the AAI 0.19 naturally occur as (homo)dimer in solution (Buonocore et al. 1984, Oda et al. 1997).

Although long-lasting (more than 1 year) adherence to GFD in CLD patients led to disappearance of $\mathrm{Ab}$ against gliadins and tTG (serological markers of the CLD) indicating compliance to the diet in all patients, some of them remain positive for $\operatorname{IgA} \mathrm{Ab}$ against non-gluten AAI 0.19 protein in our study. The persistence of these $\mathrm{Ab}$ may be explained by the presence of a low amount of AAI 0.19 in the diet and its potent immunostimulatory effect on mucosal immune system of patients with CLD, represented predominantly by $\operatorname{IgA}$ isotype. The small hydrophilic molecule of AAI 0.19 could be present in deproteinized grain starch utilized for GFD diet (Täufel et al. 1996, Gazza et al. 2016). On the other hand, the phenomenon of residual and selective $\mathrm{Ab}$ reactivity against AAI 0.19 in CLD patients on a GFD is hardly explicable as a difference between the dynamics of IgA and IgG anti-AAI 0.19 isotypes. However, it could be partly explained as part of homeostatic mechanisms including isotype switching induced by increased expression of IL-10 and TGF- $\beta$ as a consequence of homeostatic mechanisms during the exclusion of residual, harmless, antigen at mucosal surfaces.

Eventually, the immune reactivity against the AAI 0.19 (and other AAIs and amylase/trypsin inhibitors) could also be the results of cross-reactivity induced by molecular mimicry between the AAI 0.19 and other foodstuff constituents or components of altered intestinal microbiota, which is considered to play important role in CLD pathogenesis (Verdu et al. 2015). The AAI 0.19 was originally described as allergen in baker's asthma and wheat allergy (Walsh and Howden 1989, Pfeil et al. 1990, Fränken et al. 1994, Amano et al. 1998, James et al. 1997, Zapatero et al. 2003, Šotkovský et al. 2008, Šotkovský et al. 2011, Kusaba-Nakayama et al. 2001). Hence, production of IgG and IgA Ab against AAI 0.19 could be a physiological response preventing allergic reaction in some CLD patients. None of the CLD patients in our study has allergy symptoms and all patients possess a physiological level of serum IgE. For this reason we can hypothesize that the initial stage (or active) of CLD, associated with damage of small gut mucosa, involves also the production of specific $\operatorname{IgE}$ due to elevated levels of IL-4 (Manavalan et al. 2010). The pathogenic mechanism of allergic reaction and its typical dynamics is probably suppressed or mitigated by the presence of IgA and IgG anti-AAI 0.19 Ab. Finally, the IgA anti-AAI 0.19 Ab perseverance in CLD patients on GFD could be partially caused by $A b$ cross-reactivity 
of mucosal B-cells with a structurally similar antigen/ autoantigen. The role of anti-AAI 0.19 Ab is not known but the effect of various isotypes of anti-AAI Ab can be different. The IgA and IgG Ab could interfere with the stimulation of antigen presenting cells by AAI 0.19 and can block the epitopes for $\operatorname{IgE} \mathrm{Ab}$ and in such away prevent allergy reaction. Though the AAI 0.19 and AAI 0.28 have been known as allergens for many years, key IgE epitope sequence has been proposed only for AAI 0.28 (amino acids 9-26). The epitope structure of AAI 0.19 is not satisfactorily characterized. Interestingly, regardless of $60 \%$ sequential similarity between these two inhibitors, the amino acid homology between N-terminal parts of these proteins, which in AAI 0.28 is immunodominant for $\mathrm{IgE} \mathrm{Ab}$ of patients suffering from wheat and related allergy, is approximately only $33 \%$ (Walsh and Howden 1989). However, our results clearly indicate a strong antigenicity of AAI 0.19 for CLD patients and some of the healthy individuals. Interestingly, recently used selection criteria in breeding programs for new, high-yield wheat varieties prefer an increased amylase/trypsin inhibitors content in wheat grain due to improving plant pest-resistance (Ryan 1990, Cordain 1999, Sands et al. 2009, Boukid et al. 2017).

In conclusion, our work contributes to characterization of antigenicity of wheat non-gluten protein AAI 0.19, which possesses adjuvant properties for CLD patients and is the allergen in wheat allergy and baker's asthma. In any event, the production of IgA and
IgG against this protein in some CLD patients suggests advanced and clinically significant immune reaction against this food component. The relatively high prevalence of $\mathrm{Ab}$ against wheat non-gluten allergen AAI 0.19 justifies future analysis of the role of these $\mathrm{Ab}$ and AAI 0.19 in CLD and in general population. What remains for the analysis of anti-AAI $0.19 \mathrm{Ab}$ role and diagnostic value is to characterize also the occurrence of $\mathrm{Ab}$ against AAI 0.19 in diseases associated with CLD and allergic diseases.

\section{Conflict of Interest}

There is no conflict of interest.

\section{Acknowledgements}

The work was supported by projects 13-14608S of the Czech Science Foundation, TA04010762 and TH03010019 of Technology Agency of the Czech Republic, COST Action FA1402 "ImpARAS", and Institutional Research Concept RVO: 61388971.

\begin{abstract}
Abbreviations
Ab, antibodies; AAI 0.19, alpha-amylase inhibitor 0.19; AAI 0.28, alpha-amylase inhibitor 0.28; AU, arbitrary units; C, healthy controls; CLD, celiac disease; GFD, gluten-free diet; IgA, immunoglobulin A; $\operatorname{IgE}$, immunoglobulin E; IgG, immunoglobulin G; O. D., optical density.
\end{abstract}

\section{References}

AMANO M, OGAWA H, KOJIMA K, KAMIDAIRA T, SUETSUGU S, YOSHIHAMA M, SATOH T, SAMEJIMA T, MATSUMOTO I: Identification of the major allergens in wheat flour responsible for baker's asthma. Biochem J 330: 1229-1234, 1998.

ARRANZ E, FERGUSON A: Intestinal antibody pattern of celiac disease: occurrence in patients with normal jejunal biopsy histology. Gastroenterology 104: 1263-1272, 1993.

BALAKIREVA AV, ZAMYATNIN AA: Properties of gluten intolerance: gluten structure, evolution, pathogenicity and detoxification capabilities. Nutrients 8: pii: E644, 2016.

BJÖRCK S, LINDEHAMMER SR, FEX M, AGARDH D: Serum cytokine pattern in young children with screening detected coeliac disease. Clin Exp Immunol 179: 230-235, 2015.

BOUKID F, PRANDI B, SFORZA S, SAYAR R, SEO YW, MEJRI M, YACOUBI I: Understanding the effects of genotype, growing year, and breeding on Tunisian durum wheat allergenicity. 1. The Baker's asthma case. J Agric Food Chem 65: 5831-5836, 2017.

BRAR P, LEE AR, LEWIS SK, BHAGAT G, GREEN PH: Celiac disease in African-Americans. Dig Dis Sci 51: 1012-1015, 2006.

BUONOCORE V, GIARDINA P, PARLAMENTI R, POERIO E, SILANO V: Characterisation of chicken pancreas alpha-amylase isozymes and interaction with protein inhibitors from wheat kernel. J Sci Food Agric 35 : 225-232, 1984. 
BURGER JPW, DE BROUWER B, INTHOUT J, WAHAB PJ, TUMMERS M, DRENTH JPH: Systematic review with meta-analysis: Dietary adherence influences normalization of health-related quality of life in coeliac disease. Clin Nutr 36: 399-406, 2017.

CATASSI C, FASANO A: Celiac disease diagnosis: simple rules are better than complicated algorithms. Am J Med 123: 691-693, 2010.

CHAN TD, BRINK R: Affinity-based selection and the germinal center response. Immunol Rev 247: 11-23, 2012.

CHOWERS Y, MARSH MN, DE GRANDPRE L, NYBERG A, THEOFILOPOULOS AN, KAGNOFF MF: Increased proinflammatory cytokine gene expression in the colonic mucosa of coeliac disease patients in the early period after gluten challenge. Clin Exp Immunol 107: 141-147, 1997.

CORDAIN L: Cereal grains: humanity’s double-edged sword. World Rev Nutr Diet 84: 19-73, 1999.

ELLI L, BRANCHI F, TOMBA C, VILLALTA D, NORSA L, FERRETTI F, RONCORONI L, BARDELLA MT: Diagnosis of gluten related disorders: celiac disease, wheat allergy and non-celiac gluten sensitivity. World $J$ Gastroenterol 21: 7110-7119, 2015.

FRÄNKEN J, STEPHAN U, MEYER HE, KÖNIG W: Identification of alpha-amylase inhibitor as a major allergen of wheat flour. Int Arch Allergy Immunol 104: 171-174, 1994.

GAZZA L, GAZZELLONI G, TADDEI F, LATINI A, MUCCILLI V, ALFIERI M, CONTI S, REDAELLI R, POGNA NE: The starch-bound alpha-amylase/trypsin-inhibitors in Avena. Mol Genet Genomics 291: 2043-2054, 2016.

GELDERMAN KA, DROP AC, TROUW LA, BOUMA G, VAN HOOGSTRATEN IM, VON BLOMBERG BM: Serum autoantibodies directed against transglutaminase-2 have a low avidity compared with alloantibodies against gliadin in coeliac disease. Clin Exp Immunol 177: 86-93, 2014.

GUJRAL N, FREEMAN HJ, THOMSON AB: Celiac disease: prevalence, diagnosis, pathogenesis and treatment. World J Gastroenterol 18: 6036-6059, 2012.

HUEBENER S, TANAKA CK, UHDE M, ZONE JJ, VENSEL WH, KASARDA DD, BEAMS L, BRIANI C, GREEN PH, ALTENBACH SB, ALAEDINI A: Specific nongluten proteins of wheat are novel target antigens in celiac disease humoral response. J Proteome Res 14: 503-511, 2015.

HUSBY S, KOLETZKO S, KORPONAY-SZABÓ IR, MEARIN ML, PHILLIPS A, SHAMIR R, TRONCONE R, GIERSIEPEN K, BRANSKI D, CATASSI C, LELGEMAN M, MÄKI M, RIBES-KONINCKX C, VENTURA A, ZIMMER KP; ESPGHAN WORKING GROUP ON COELIAC DISEASE DIAGNOSIS; ESPGHAN GASTROENTEROLOGY COMMITTEE; EUROPEAN SOCIETY FOR PEDIATRIC GASTROENTEROLOGY, HEPATOLOGY, AND NUTRITION: European Society for Pediatric Gastroenterology, Hepatology, and Nutrition guidelines for the diagnosis of coeliac disease. J Pediatr Gastroenterol Nutr 54: 136-160, 2012.

JAMES JM, SIXBEY JP, HELM RM, BANNON GA, BURKS AW: Wheat alpha-amylase inhibitor: a second route of allergic sensitization. J Allergy Clin Immunol 99: 239-244, 1997.

JUNKER Y, ZEISSIG S, KIM SJ, BARISANI D, WIESER H, LEFFLER DA, ZAVALLOS V, LIBERMANN TA, DILLON S, FREITAG TL, KELLY CP, SCHUPPAN D: Wheat amylase trypsin inhibitors drive intestinal inflammation via activation of toll-like receptor 4. J Exp Med 209: 2395-2408, 2012.

KASARDA DD: Can an increase in celiac disease be attributed to an increase in the gluten content of wheat as a consequence of wheat breeding? J Agric Food Chem 61: 1155-1159, 2013.

KONTAKOU M, PRZEMIOSLO RT, STURGESS RP, LIMB GA, ELLIS HJ, DAY P, CICLITIRA PJ: Cytokine mRNA expression in the mucosa of treated coeliac patients after wheat peptide challenge. Gut 37: 52-57, 1995.

KUSABA-NAKAYAMA M, KI M, KAWADA E, SATO M, IKEDA I, MOCHIZUKI T, IMAIZUMI K: Intestinal absorbability of wheat allergens, subunits of a wheat alfa- amylase inhibitor, expressed by bacteria. Biosci Biotechnol Biochem 65: 2448-2455, 2001.

LAEMMLI UK, FAVRE M: Maturation of the head of bacteriophage T4: I. DNA packaging events. J Mol Biol 80: $575-599,1973$.

LEBWOHL B, SANDERS DS, GREEN PHR: Coeliac disease. Lancet 391: 70-81, 2018.

MANAVALAN JS, HERNANDEZ L, SHAH JG, KONIKKARA J, NAIYER AJ, LEE AR, CIACCIO E, MINAYA MT, GREEN PH, BHAGAT G: Serum cytokine elevations in celiac disease: association with disease presentation. Hum Immunol 71: 50-57, 2010. 
NEVORAL J, KOTALOVA R, HRADSKY O, VALTROVA V, ZARUBOVA K, LASTOVICKA J, NEUBERTOVA E, TRNKOVA M, BRONSKY J: Symptom positivity is essential for omitting biopsy in children with suspected celiac disease according to the new ESPGHAN guidelines. Eur J Pediatr 173: 497-502, 2014.

ODA Y, MATSUNAGA T, FUKUYAMA K, MIYAZAKI T, MORIMOTO T: Tertiary and quaternary structures of $0.19 \alpha$-amylase inhibitor from wheat kernel determined by $\mathrm{X}$ ray analysis at $2.06 \AA$ resolution. Biochemistry 36: 13503-13511, 1997.

OSMAN M, TAHA B, AL DUBONI G: Assessment of the response to gluten-free diet in an Iraqi population with coeliac disease. A histological and serological follow-up study. Arch Med Sci 10: 294-299, 2014.

PARADA A, ARAYA M, PÉREZ-BRAVO F, MÉNDEZ M, MIMBACAS A, MOTTA P, MARTÍN G, BOTERO J, ESPINOSA N, ALARCON T, CANALES P: Amerindian mtDNA haplogroups and celiac disease risk HLA haplotypes in mixed-blood Latin American patients. J Pediatr Gastroenterol Nutr 53: 429-434, 2011.

PEKKI H, KURPPA K, MÄKI M, HUHTALA H, LAURILA K, ILUS T, KAUKINEN K: Performing routine followup biopsy 1 year after diagnosis does not affect long-term outcomes in coeliac disease. Aliment Pharmacol Ther 45: 1459-1468, 2017.

PFEIL T, SCHWABL U, ULMER WT, KÖNIG W: Western blot analysis of water-soluble wheat flour (Triticum vulgaris) allergens. Int Arch Allergy Appl Immunol 91: 224-231, 1990.

REVERBERI R: The statistical analysis of immunohaematological data. Blood Transfus 6: 37-45, 2008.

RYAN CA: Protease inhibitors in plants: genes for improving defenses against insects and pathogens. Annu Rev Phytopathol 28: 425-449, 1990.

SANDS DC, MORRIS CE, DRATZ EA, PILGERAM A: Elevating optimal human nutrition to a central goal of plant breeding and production of plant-based foods. Plant Sci 177: 377-389, 2009.

SCHUPPAN D, ZEVALLOS V: Wheat amylase trypsin inhibitors as nutritional activators. Dig Dis 33: 260-263, 2015.

STAMNAES J, IVERSEN R, DU PRÉ MF, CHEN X, SOLLID LM: Enhanced B-cell receptor recognition of the autoantigen transglutaminase 2 by efficient catalytic self multimerization. PLoS One 10: e0134922, 2015.

ŠOTKOVSKÝ P, HUBÁLEK M, HERNYCHOVÁ L, NOVÁK P, HAVRANOVÁ M, ŠETINOVÁ I, KITANOVIČOVÁ A, FUCHS M, STULÍK J, TUČKOVÁ L: Proteomic analysis of wheat proteins recognized by IgE antibodies of allergic patients. Proteomics 8: 1677-1691, 2008.

ŠOTKOVSKÝ P, SKLENÁŘ J, HALADA P, CINOVÁ J, ŠETINOVÁ I, KAINAROVÁ A, GOLIÁŠ J, PAVLÁSKOVÁ K, HONZOVÁ S, TUČKOVÁ L: A new approach to the isolation and characterization of wheat flour allergens. Clin Exp Allergy 41: 1031-1043, 2011.

TÄUFEL A, LÜDER W, PROLL J: Alpha-amylase inhibitors and soluble dietary fiber in rye: partial purification and effect on postprandial glycemia (in German). Z Ernahrungswiss 35: 199-205, 1996.

TURSI A, BRANDIMARTE G, GIORGETTI GM: Prevalence of antitissue transglutaminase antibodies in different degrees of intestinal damage in celiac disease. J Clin Gastroenterol 36: 219-221, 2003.

VERDU EF, GALIPEAU HJ, JABRI B: Novel players in coeliac disease pathogenesis: role of the gut microbiota. Nat Rev Gastroenterol Hepatol 12: 497-506, 2015.

WAHAB PJ, MEIJER JW, MULDER CJ: Histologic follow-up of people with celiac disease on a gluten-free diet: slow and incomplete recovery. Am J Clin Pathol 118: 459-463, 2002.

WALSH BJ, HOWDEN MEH: A method for the detection of IgE binding sequences of allergens based on a modification of epitope mapping. J Immunol Methods 121: 275-280, 1989.

WOLF J, PETROFF D, RICHTER T, AUTH MKH, UHLIG HH, LAASS MW, LAUENSTEIN P, KRAHL A, HÄNDEL N, DE LAFFOLIE J, HAUER AC, KEHLER T, FLEMMING G, SCHMIDT F, RODRIGUES A, HASENCLEVER D, MOTHES T: Validation of antibody-based strategies for diagnosis of pediatric celiac disease without biopsy. Gastroenterology 153: 410-419, 2017.

ZAPATERO M, MARTÍNEZ MI, ALONSO E, SALCEDO G, SÁNCHEZ-MONGE R, BARBER D, LOMBARDERO M: Oral wheat flour anaphylaxis related to wheat alpha-amylase inhibitor subunits CM3 and CM16. Allergy 58: 956, 2003.

ZEVALLOS VF, RAKER V, TENZER S, JIMENEZ-CALVENTE C, ASHFAQ-KHAN M, RÜSSEL N, PICKERT G, SCHILD H, STEINBRINK K, SCHUPPAN D: Nutritional wheat amylase-trypsin inhibitors promote intestinal inflammation via activation of myeloid cells. Gastroenterology 152: 1100-1113, 2017. 